\title{
Ultrasonic Metal Welding of Multilayered Copper Foils to Nickel-Plated Copper Sheet in Lithium-Ion Battery Cell
}

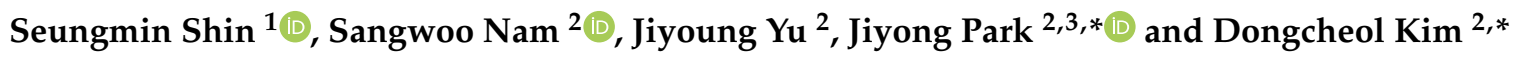 \\ 1 Monisys Co., Ltd., 116, Mullaebuk-ro, Yeongdeungpo-gu, Seoul 07293, Korea; glipzide@naver.com \\ 2 Advanced Joining \& Additive Manufacturing R\&D Department, Korea Institute of Industrial Technology, \\ 156 Gaetbeol-ro, Yeonsu-Gu, Incheon 21999, Korea; chak1843@kitech.re.kr (S.N.); willow@kitech.re.kr (J.Y.) \\ 3 Department of Convergence Manufacturing System Engineering, University of Science and \\ Technology (UST), 217 Gajeong-ro, Yuseong-gu, Daejeon 34113, Korea \\ * Correspondence: j.park@kitech.re.kr (J.P.); dckim@kitech.re.kr (D.K.)
}

Citation: Shin, S.; Nam, S.; Yu, J.; Park, J.; Kim, D. Ultrasonic Metal Welding of Multilayered Copper Foils to Nickel-Plated Copper Sheet in Lithium-Ion Battery Cell. Metals 2021, 11, 1195. https://doi.org/10.3390/ met11081195

Academic Editors: João

Pedro Oliveira and Zhi Zeng

Received: 24 June 2021

Accepted: 23 July 2021

Published: 27 July 2021

Publisher's Note: MDPI stays neutral with regard to jurisdictional claims in published maps and institutional affiliations.

Copyright: (c) 2021 by the authors. Licensee MDPI, Basel, Switzerland. This article is an open access article distributed under the terms and conditions of the Creative Commons Attribution (CC BY) license (https:/ / creativecommons.org/licenses/by/ $4.0 /)$.

\begin{abstract}
The battery performance of electric vehicles depends on the density and capacity of the battery; thus, the battery cells must be assembled in as many layers as possible. Electric vehicle batteries are typically composed of several cells which form modules connected by busbars, with dozens of modules manufactured as battery packs. The ultrasonic metal welding (UMW) technology is applied to such multilayered foil welding. This study analyzed UMW to ensure the weldability of multilayered $\mathrm{Cu}$ foils and a Ni-plated $\mathrm{Cu}$ strip in lithium-ion battery cells through various approaches. In UMW, the effect of the alignment on weld production and quality were examined through the energy and mechanical performance of the weld by conducting comparative experiments on the alignment of the horn and anvil. Additionally, the effects of UMW process parameters, such as the welding pressure, amplitude, and welding time, were statistically analyzed. The weldability evaluation and characteristic analysis were performed based on these variables. Furthermore, the cross-sectional shapes and microstructure behavior of the Ni layers were analyzed based on the weld quality.
\end{abstract}

Keywords: lithium-ion battery; ultrasonic metal welding; alignment; weldability; multilayered

\section{Introduction}

The demand for hybrid and electric vehicles with low carbon emissions has increased rapidly in recent years as the environmental regulations corresponding to the reduction of particulate matter and greenhouse gas emissions have been strengthened in the automobile industry [1]. The powertrain system of electric vehicles uses an electric motor powered by a battery, and the performance of the vehicles depends on the density and capacity of the battery. Therefore, a battery manufacturing technology that connects numerous cells is required to provide high-capacity batteries for electric vehicles. The batteries for electric vehicles are typically manufactured by connecting several cells and a bus-bar to form a single module, and dozens of modules are assembled into a battery pack [2]. Since stable electrical conductivity and mechanical strength are essential for welding the battery cells and the modules, a welding technology that can meet these requirements is essential. Battery cells, which directly affect the battery performance, are connected to multilayered foils and tabs. Materials such as $\mathrm{Cu}$ and $\mathrm{Al}$, which present excellent electrical conductivity and mechanical properties, are used as the main materials. Resistance spot welding, laser welding, and the ultrasonic metal welding (UMW) have been used to weld the multilayered foils with tabs similar to battery cell welding. Although resistance spot welding is advantageous due to its speed and simple automation, it is unsuitable for $\mathrm{Cu}$ materials with high thermal and electrical conductivity because the over-welded area is high [3,4]. Additionally, it is difficult to produce sound welds using resistance spot welding owing to the thin $\mathrm{Cu}$ foils [2]. Even though laser welding, which is specialized in automation, presents high 
production speed, the initial cost of the equipment is high, and it is difficult to ensure the welding conditions for $\mathrm{Cu}$ materials with a high thermal conductivity, high reflectivity, and low absorption rate. Furthermore, a large number of intermetallic compounds are formed during fusion welding, which is difficult to control $[5,6]$. Conversely, the UMW process is simple and advantageous owing to its low dependence on materials $[7,8]$, and because it allows wide welds in a short period by minimizing the formation of the intermetallic compounds and energy loss at the contact part $[9,10]$. Therefore, this process has gained widespread interest as a suitable technology for battery cell welding.

Various research groups have conducted studies on the process characteristics, welding phenomena, weldability evaluation, and welding characteristics of thin $\mathrm{Cu}$ plates to expand the applicability of the UMW process. Luo et al. reported the weld formation and mechanical interlocking of the interface in multilayered (four sheets) welding of Ni-plated $\mathrm{Cu}$ materials [11]. Elangovan et al. analyzed the correlation between the welding strength and welding conditions based on Taguchi's robust design and an ANOVA analysis using a pure $0.2 \mathrm{~mm} \mathrm{Cu}$ sheet [12]. Yang et al. conducted a study on the correlation between the tensile strength and microhardness corresponding to the welding energy and microstructural analysis obtained through complex dynamic recrystallization and grain growth at the interfaces [13]. Additionally, Arimoto et al. performed an in situ observation of the formation of weld bonding and a macroscopic plastic flow using a high-speed camera with a combination of 17 layers of $7.0 \mu \mathrm{m}$ thick $\mathrm{Cu}$ foils and a $0.2 \mathrm{~mm}$ thick Ni-plated $\mathrm{Cu}$ sheet [14]. Su et al. studied recrystallization behavior by analyzing the microstructures and mechanical properties of pure $\mathrm{Cu}$ materials [15]. Das et al. investigated welding quality through various analyzes using $\mathrm{Al}$ and $\mathrm{Cu}$ materials used for tab-to-busbar welding combination [16], and compared mechanical strength, electrical resistance, and thermal behavior [17]. Most related studies focused on single tab-to-tab or tab-to-busbar welding. However, in actual welding, studies on the welding of high-density battery cells of a foil-to-tab structure using multilayered foil are insufficient.

In this study, the UMW process is performed for 40 layers of multilayered $\mathrm{Cu}$ foils and a thin Ni-plated $\mathrm{Cu}$ foil strip, which are applied to high-density lithium-ion battery. The welding experiments were conducted using an $8 \mu \mathrm{m}$ thick multilayered $\mathrm{Cu}$ foil and a $0.2 \mathrm{~mm}$ thick Ni-plated $\mathrm{Cu}$ strip. The welding characteristics are analyzed through various approaches to ensure the weldability of multilayered $\mathrm{Cu}$ foils and Ni-plated $\mathrm{Cu}$ strips, which are applied to the lithium-ion battery cells in the UMW process. The effect of alignment on the weld production and quality is analyzed through the energy and mechanical performance of the weld by performing comparison experiments based on the alignment of the horn and the anvil in the UMW process. Additionally, the effects of the UMW process parameters, such as the welding pressure, amplitude, and welding time, are statistically analyzed. The weldability evaluation and characteristic analyses are performed based on these variables. Furthermore, the cross-sectional shape and microstructure behavior of the Ni layers are analyzed (FE-SEM: field emission scanning electron microscope) based on the weld quality.

\section{Experimental Procedure}

\subsection{Materials and Experimental Methods}

In this study, $8 \mu \mathrm{m}$ thick $99.99 \mathrm{wt} . \%$ pure $\mathrm{Cu}$ foils and a $0.2 \mathrm{~mm}$ thick nickel-plated copper strip were used, which were applied to the cathode cell of an electric vehicle battery. A UMW machine with a $3 \mathrm{~kW}$ maximum output power, operating at a frequency of $20 \mathrm{kHz}$, was used as the welding equipment. A schematic of the UMW machine is shown in Figure 1. The power source converts the AC power into high-frequency electrical energy and then converts it into high-frequency mechanical vibration energy using a converter when an alternating current (AC) power of $60 \mathrm{~Hz}$ is applied to the power supply/controller. Subsequently, the mechanical vibration signal is amplified by the booster and then transmitted to the welding material through a tool called a horn. The 
transferred welding materials are welded using the frictional heat generated by $20 \mathrm{kHz}$ ultrasonic vibration energy.

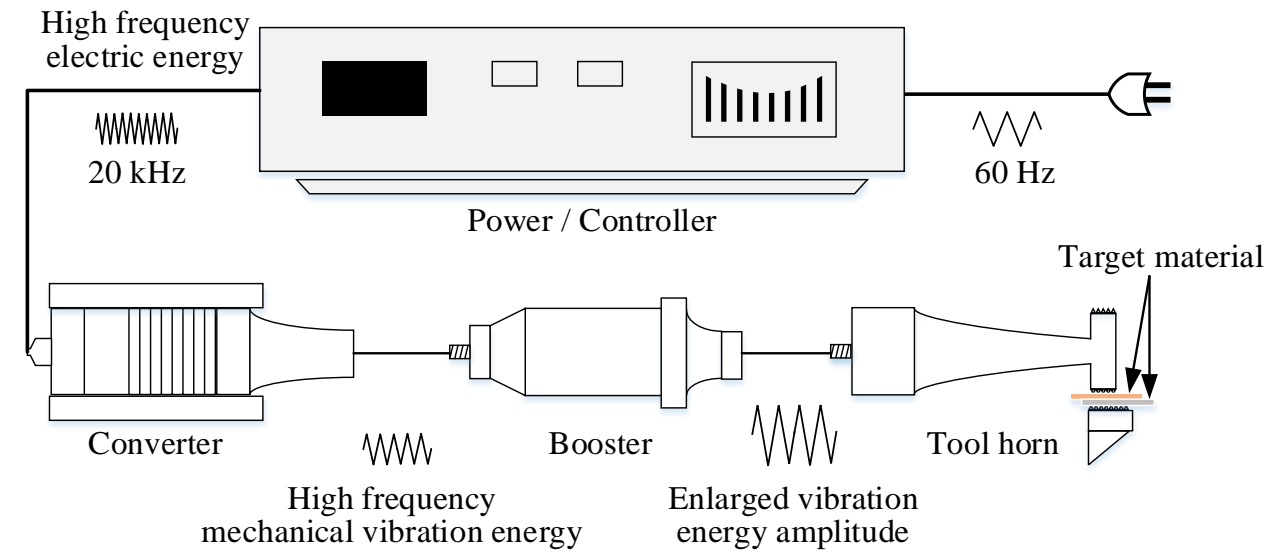

Figure 1. Schematic of ultrasonic welding system.

The welding test specimens, $20 \mathrm{~mm}$ in width $\times 50 \mathrm{~mm}$ in length $\times 8 \mu \mathrm{m}$ and $0.2 \mathrm{~mm}$ in thickness, as shown in Figure 2a, were used to perform the T-peel test for the weldability evaluation. As shown in Figure 2b, the welding was performed by placing one layer of the nickel-plated copper strip on the anvil side and 40 layers of $\mathrm{Cu}$ foils, which were arranged to overlap on the horn side to which vibrations were applied. The horn and anvil used in the experiment were fabricated as shown in Figure 2c, d for the stable welding of the $40 \mathrm{Cu}$ foil sheets and the $\mathrm{Cu}-\mathrm{Ni}$ strip.

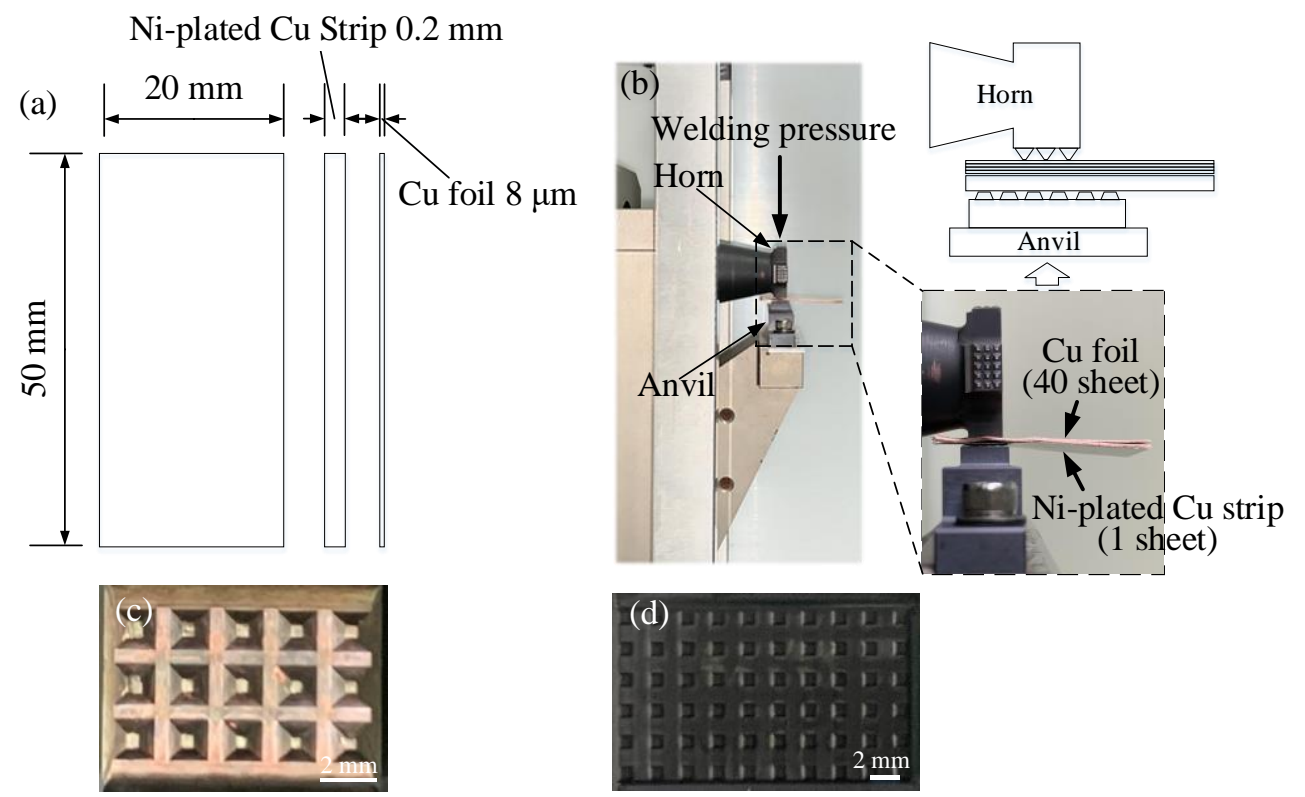

Figure 2. (a) Test sheet size; (b) joint type used in the experiment; (c) shape of tool horn; and (d) shape of anvil.

The UMW process variables include the welding time, amplitude, and welding pressure. This experiment was conducted under the conditions listed in Table 1 to derive the welding lobe area of the target material. 
Table 1. Welding experimental conditions.

\begin{tabular}{cc}
\hline Variables & Levels \\
\hline Welding pressure $($ bar $)$ & $3,4,5,6$ \\
Peak-to-peak amplitude $(\mu \mathrm{m})$ & $40,45,50$ \\
Welding time $(\mathrm{s})$ & $0.3,0.5,0.7,0.9$ \\
\hline
\end{tabular}

There is no international standard for the evaluation of the multilayered joints manufactured by ultrasonic welding, and the T-peel test was employed to measure the strength of the joints. The weld strength was determined as the maximum load until failure on the load-displacement curve. The equipment for the T-peel test consists of a motorized test stand (MX2-500N, Imada, Aichi, Japan) and a digital force measurement gauge (DS2-500N, Imada, Aichi, Japan). For the T-peel test, ultrasonic-welded samples were bent 90 degrees in both directions by separating a tab and 40 sheets to form a T shape shown in Figure 3. The 40 foils were held by the upper grip and a tab by the lower grip. The test was carried out at room temperature with a crosshead speed of $50 \mathrm{~mm} / \mathrm{min}$.

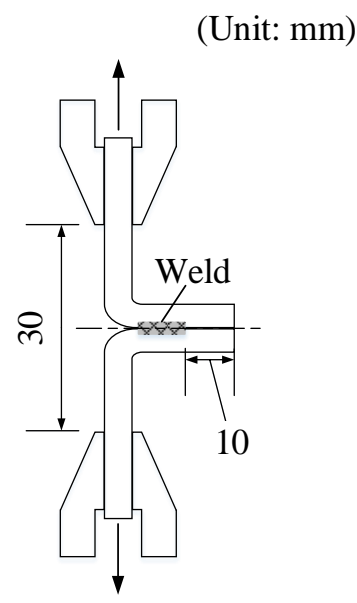

Figure 3. Schematic diagram of T-peel test method for weld performance evaluation.

For the cross-section analysis, the center of the horizontal line of the indentation mark pressed with a horn was observed using optical microscopy and FE-SEM. The cross-section was polished with $\mathrm{SiC}$ paper up to 4000 grit and diamond paste. The microstructure was analyzed after etching for $1 \mathrm{~min}$ using the etchant by mixing distilled water, ammonium hydroxide, and hydrogen peroxide in a volume ratio of 5:5:1.

\subsection{Weldability Evaluation}

Since the shape of the horn and anvil must be designed according to the material combination for the UMW welding of multilayered foils, a clear establishment of the welding standards is difficult. However, a total of 40 sheets of multilayered foil cathode cells were welded using the UMW process in this study. The UMW experiments were repeated with the current representative material combinations and welding standard evaluated based on the experimental data. For the evaluation method, the evaluation standards were divided according to the weld strength of the peak values $(\mathrm{N})$ through the T-peel test and the appearance condition. The evaluation standards were classified into under weld, good weld, and over weld, which are listed in Table 2. As can be seen from the Table 2, in the case of under weld, it shows weak maximum T-peel load of less than $40 \mathrm{~N}$ and shows the aspect of interfacial fracture. In the case of good weld and over weld, interfacial fracture shapes are not seen, but unlike a good weld showing a maximum T-peel load of $40 \mathrm{~N}$ or more, the measured strength values of the over weld were not constant, 
and the foil color was changed, which may give a problem to the material properties of the foil such as electrical conductivity.

Table 2. Weld evaluation standards.

\begin{tabular}{|c|c|c|c|}
\hline Weld Quality & Under Weld & Good Weld & Over Weld \\
\hline Maximum T-peel load & $<40 \mathrm{~N}$ & $>40 \mathrm{~N}$ & $\mathrm{~N} / \mathrm{A}$ \\
\hline Discoloration (Foil) & $x$ & $x$ & o \\
\hline Weld appearance & & & \\
\hline
\end{tabular}

\section{Results and Discussion}

\subsection{Alignment Effect}

The upper parts of the horn specimen were clamped with a constant welding pressure and then welded on the specimen through the friction of the mechanical vibration energy in the UMW process. Table 3 shows the weld appearance and the cross section of the material combination used in this study. In the case of misalignment, wrinkles are observed on the weld surface due to the interference of the horn-foil contact and the anvil-tab contact, and the weld cross-sectional shapes follow left-right asymmetry due to the misalignment of the contacts between the horn and anvil. Conversely, very few wrinkles are observed on the weld surface in the case of alignment, and the left-right symmetric weld is formed. Additionally, a narrower welded area is formed in the case of misalignment when compared to the case when it is aligned.

Table 3. Weld surface appearance and cross-section according to the horn alignment.

\begin{tabular}{|c|c|c|c|c|}
\hline & \multicolumn{2}{|c|}{ Misalignment } & \multicolumn{2}{|c|}{ Alignment } \\
\hline & Horn-Foil & Anvil-Tap & Horn-Foil & Anvil-Tap \\
\hline \multicolumn{5}{|c|}{ Weld Appearance } \\
\hline Cross-section & & & & \\
\hline
\end{tabular}

Table 4 shows the fracture surface of the weld corresponding to the horn alignment setup under the same welding conditions. The fracture surfaces of the weld are formed under four different welding conditions depending on the alignment of the electrode. The separation phenomenon is predominately observed in the case of misalignment due to the fracture of the weld between the nickel-plated copper strip and the $\mathrm{Cu}$ foil. Conversely, in the case of alignment, the fracture is observed only in the $\mathrm{Cu}$ foil and not in the weld. Therefore, it is inferred that the fracture is observed in the $\mathrm{Cu}$ foil and not the weld, because the strength of the weld is greater than that of the $\mathrm{Cu}$ foil. 
Table 4. Fracture surface of the weld according to horn alignment state.

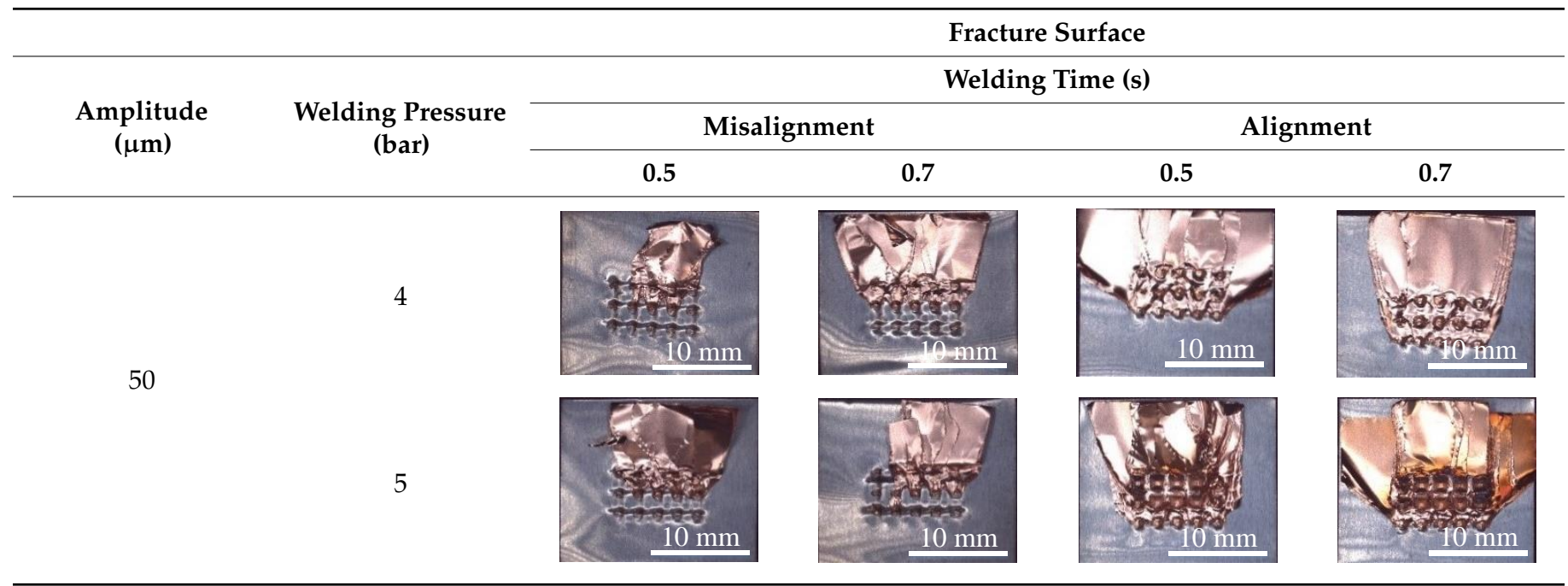

In the case of misalignment, as shown in Figure 4a, since the horn is asymmetrically set up, less welding (output) energy is generated in the area to be welded. Conversely, in the alignment setup, as shown in Figure $4 \mathrm{~b}$, the welding energy is large since the area to which the horn is welded is relatively larger than in the case of misalignment.
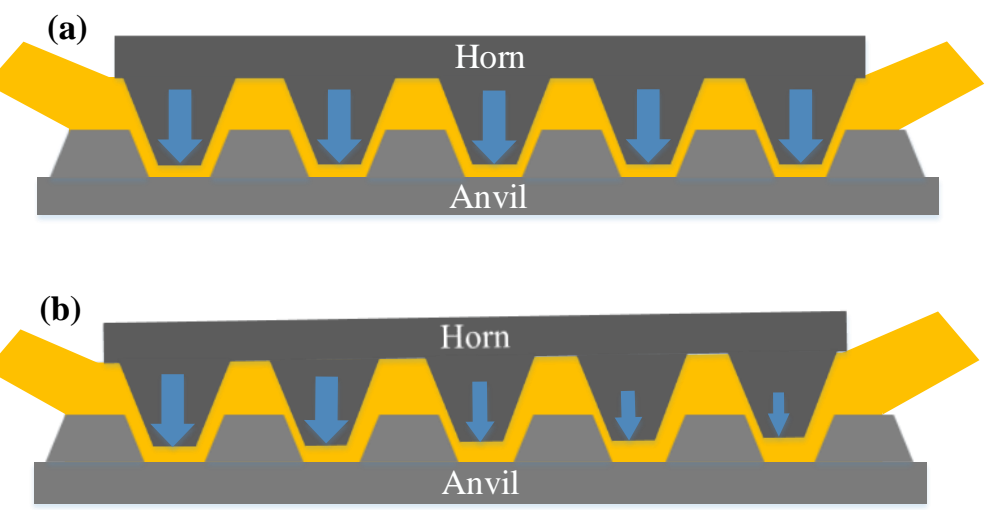

Figure 4. Schematic of (a) alignment and (b) misalignment.

Figure 5 shows a comparison of the power signal under the conditions of 4 bar and $50 \mu \mathrm{m}$ amplitude among the welding conditions listed in Table 4 , and it is verified that the power signal of proper alignment is higher than the misalignment power signal. Essentially, in the case of the alignment setup, more energy is applied to the weld than in the misalignment setup, which is involved in the creation of the weld. The comparison made corresponding to the alignment state shows that the larger the area of the weld where the horn is pressed, the higher the welding energy that is formed. Therefore, ensuring sound weldability is essential. 
Amplitude: $50 \mu \mathrm{m}$

Welding pressure: 4 bar

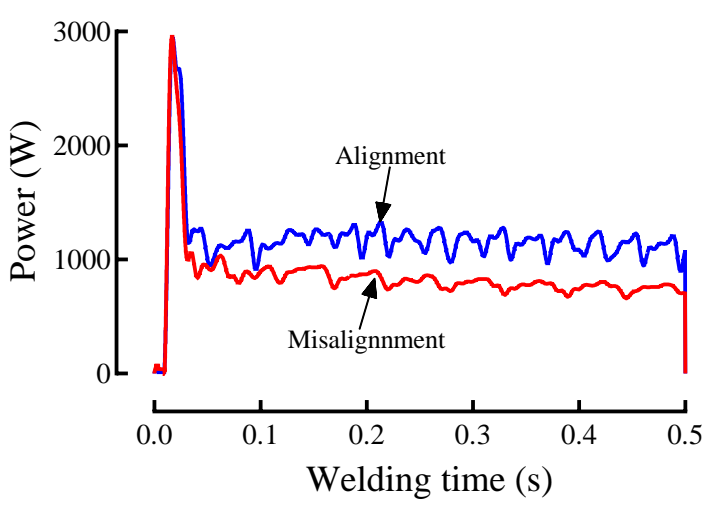

Figure 5. Comparison of power signals of misalignment and alignment under the same welding conditions.

\subsection{Weldability Evaluation}

The weldability evaluation is performed without the misalignment of the horn and the anvil, which can be classified as welding disturbance. Essentially, it is performed in a state where there is no alignment error between the horn and anvil. The experimental conditions, as listed in Table 1, are repeated twice with a full factorial design with a welding pressure at four levels, amplitude at three levels, and welding time at four levels.

Figure $6 \mathrm{a}, \mathrm{b}$ present the comparison of the relative magnitude and statistical significance of both the Pareto chart and its main effects. In the Pareto chart effect of Figure 6a, the effects of the welding pressure, $\mathrm{A}$, and the welding time, $\mathrm{C}$, are statistically significant $(\alpha=0.05)$. Furthermore, the effect of A (welding pressure) is the largest, and the effect of $B$ (amplitude) is the least in the graph. For the main effect of each factor in Figure $6 b$, the average strength increases with the increase in the welding pressure, but the average strength is not significantly affected by the amplitude. Additionally, the highest average strength is obtained at a welding time of $0.7 \mathrm{~s}$.

\section{Pareto chart of the effect}

(response is strength, $=0.05$ )

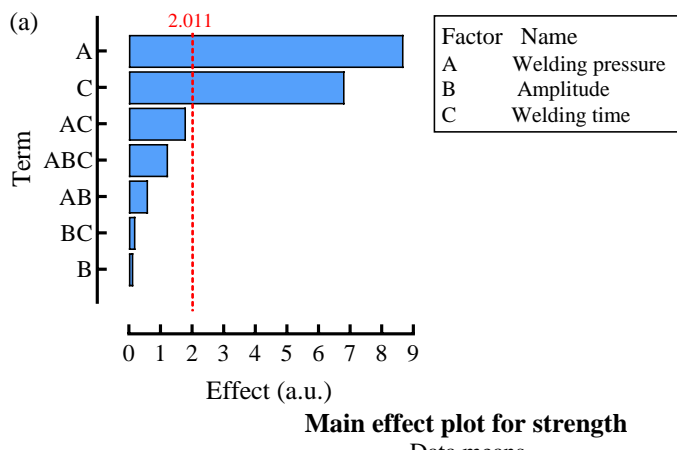

Data means
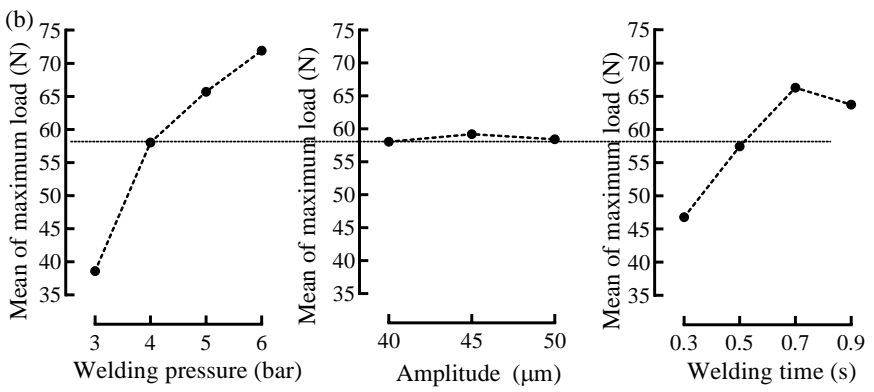

Figure 6. (a) Pareto chart effect and (b) main effect through statistical analysis. 
Figure 7 shows the welding lobe region based on the average value of maximum T-peel load based on the welding evaluation standards in Table 2. The under weld is mostly observed when the welding pressure is three bars. The standard strength value is satisfied for the welding time of $0.9 \mathrm{~s}$, but the over weld is observed because of the discoloration of the weld foils caused by the high welding energy. In the condition of the good weld, the welding pressures are $4-6$ bars, and the welding times are $0.3 \mathrm{~s}$ and $0.5 \mathrm{~s}$. Additionally, the over weld is observed in all the welding pressures and at the welding times of $0.7 \mathrm{~s}$ and $0.9 \mathrm{~s}$. Therefore, it was verified that sound weldability can be ensured in the region of the welding condition for the welding pressure of 3 bars or more and the welding time of $0.5 \mathrm{~s}$ or less.

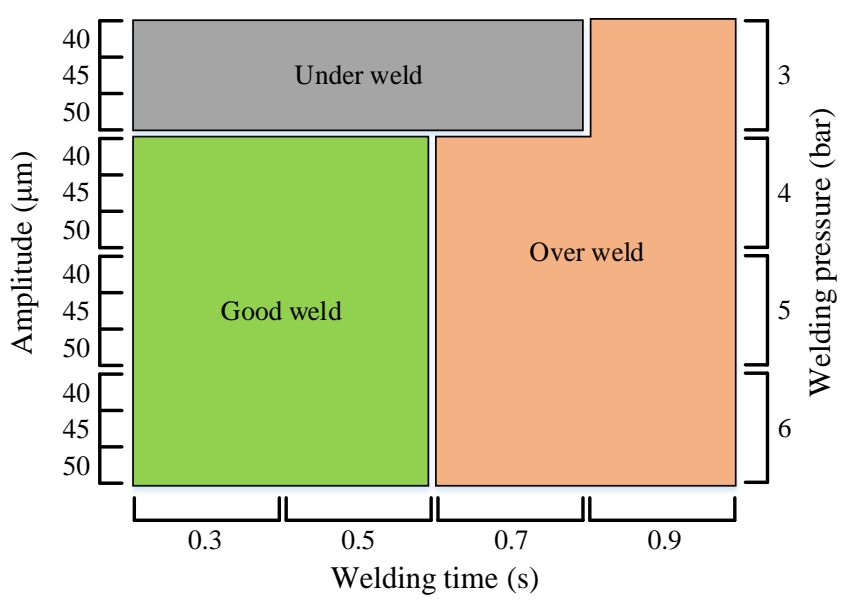

Figure 7. Weld lobe region.

\subsection{Cross-Section Analysis}

Table 5 shows the cross-sectional images corresponding to the weld quality compared with the strength values. Under the weld condition, it is verified that the strength value does not meet the standard due to unbonded region in the weld where the horn knurl is engaged with the anvil. It is observed under the process conditions of low welding pressure and welding time and is thus considered to be under-welded due to the insufficient welding energy. In the over weld condition, thinning is observed in the weld where the horn knurl is engaged with the anvil, and cracks exist on the slope of the outer sheets. Due to these two phenomena (thinning and crack), it is determined that the strength value does not meet the standard. Additionally, it is inferred that the thinning and cracking are caused by the excessive energy produced by the welding involving excessive welding pressure and welding time. Conversely, the defects such as gap, thinning, and cracking are not observed in the weld where the horn knurl is engaged with the anvil in a good weld condition. Therefore, it is concluded that the weld strength and appearance quality which satisfy the quality standards are ensured by the formation of a weld of sufficient size.

Table 5. Cross-section images and T-peel strength according to weld quality.

Weld Quality


Table 5. Cont

\begin{tabular}{lll}
\hline Weld Quality & Weld Cross-Section & Maximum Load (N) \\
Over weld & &
\end{tabular}

The weld where the horn knurl is engaged with the anvil according to the welding quality is observed using FE-SEM, and the movement and distribution of the Ni layer coated on the surface of the lower strip are analyzed through EDS (energy dispersive spectroscopy) mapping (Table 6). The Ni-coated layer of the strip has a distinctly continuous interface in the under weld, which indicates that there is no metallurgical bond between the foil layers and the strip. In the Ni layer, the coating material of the lower plate is observed all the way to the top of the weld in the over weld, which is considered as a driving force for the occurrence of thinning due to excessive plastic deformation. The Ni layer exists discontinuously by pushing and moving down to the lower part of the weld in the good weld, indicating that there is a metallurgical bond between the foil and the strip. The main purpose of nickel plating is to prevent corrosion and to enhance the weldability of highly conductive materials [18]. This is because nickel has a higher thermal and electrical resistance than copper [19]. For battery applications, the joints require high conductivity because electrical energy should be transmitted. Therefore, when the nickel layer is discontinuous at the interface, the electrical energy loss in the joint could be reduced.

Table 6. Ni and $\mathrm{Cu}$ distribution according to weld quality by EDS mapping.

\begin{tabular}{|c|c|c|c|}
\hline Weld Quality & Image & $\mathrm{Cu}$ & $\mathrm{Ni}$ \\
\hline Under weld & & & \\
\hline & & & \\
\hline Good weld & & & \\
\hline Over weld & & & \\
\hline
\end{tabular}


Figure 8 shows the etched cross-sectional images illustrating the grain size and material bonding corresponding to the welding quality. The etching solution is prepared by mixing distilled water, ammonium hydroxide, and hydrogen peroxide in a volume ratio of 5:5:1. Figure 8a shows the structure of the Ni-coated $\mathrm{Cu}$ base metal. The under weld is separated by a coating layer between the foil and the strip, and there is an unbonded region at the interface between the foils, as shown in Figure 8b. At the lower end of the strip, a recrystallization zone is formed due to deformation and frictional heat produced during the ultrasonic welding. The bond between the foil layers and the metallurgical bond between the strip and the foil are formed in the weld as shown in Figure 8c. Overall, the recrystallization zone expands, and the micronized crystal grains are observed. The deformation and the Ni layer movement due to the excessive energy flow are shown in Figure $8 d$.
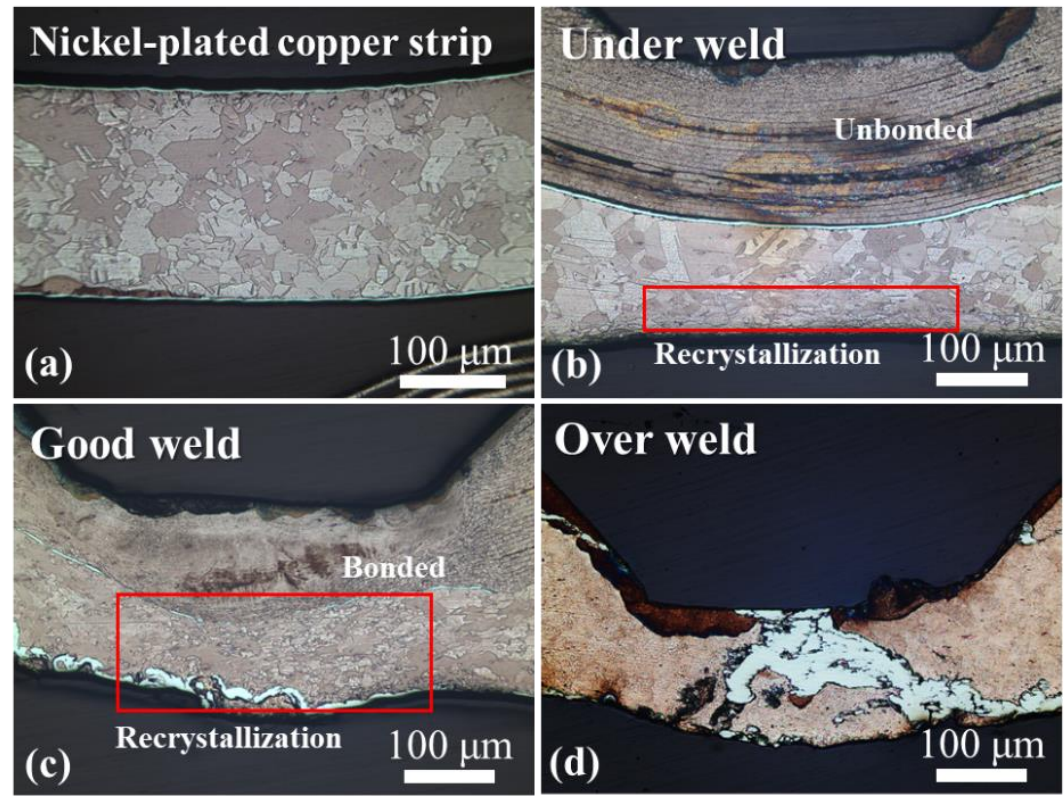

Figure 8. (a) Etched surface cross section image of Ni-coated $\mathrm{Cu}$ base metal. Etched cross-sectional images according to the welding quality of (b) under weld, (c) good weld, and (d) over weld.

\section{Conclusions}

This study analyzed the welding characteristics through various approaches to ensure the weldability of $8 \mu \mathrm{m}$ thick $\mathrm{Cu}$ foils and a $0.2 \mathrm{~mm}$ thick Ni-plated $\mathrm{Cu}$ strip, which were applied to lithium-ion battery cells in the UMW process. The conclusions drawn from the experimental results are as follows:

(1) In the UMW, it was proved that the horn alignment setup condition affects the weldability by performing comparative experiments. A sound weld can be ensured due to a high welding energy even under the same conditions by forming a higher weld area where the knurl of the horn is engaged with the anvil in the horn-aligned setup when compared to the case of misalignment.

(2) The experiment was conducted based on the designed experimental method, and the weldability was analyzed using statistical techniques. Based on the analysis of the Pareto chart and main effect, it was confirmed that the amplitude factor was almost unrelated to the average strength, and that the welding pressure and welding time factor correspond to the average strength.

(3) The welding lobe area was derived according to the weldability evaluation standards. Consequently, sound weldability was ensured in the region of welding conditions with a welding pressure of 3 bars or higher and a welding time of $0.5 \mathrm{~s}$ or lesser in the used material combination. 
(4) The cross-sectional images corresponding to the weld quality and the behavior of the Ni layer and microstructure were analyzed using FE-SEM. Consequently, it was observed that no metallurgical bond was formed in the under weld due to unbonded region in the weld where the knurl was pressed. The deformation and movement of the Ni layer were observed in the over weld because of the thinning that occurs due to the excessive flow of energy into the weld where the knurl was pressed.

(5) This study is a basic analysis of the welding of battery cell materials of multilayered foils. The obtained research results can be effectively utilized in the welding production of high-density battery cells and the development of UMW welding quality monitoring technology. The future scope of the study include the conduction of research on the development of monitoring technology for the UMW process of high-density battery cells.

Author Contributions: Conceptualization, S.S. and S.N.; methodology, S.S.; formal analysis, S.S.; investigation, S.N.; writing—original draft preparation, S.S.; writing-review and editing, J.P. and J.Y.; supervision, D.K. and J.P.; project administration and funding acquisition, D.K. and J.P. All authors have read and agreed to the published version of the manuscript.

Funding: This research was supported by the Technology Development Program (S2798672) funded by the 2019 Ministry of SMEs and Startups (MMS, Korea) and KITECH (Korea Institute of Industrial Technology) internal project(EO210005).

Institutional Review Board Statement: Not applicable.

Informed Consent Statement: Not applicable.

Data Availability Statement: Not applicable.

Conflicts of Interest: The authors declare no conflict of interest.

\section{References}

1. Chu, S.; Majumdar, A. Opportunities and challenges for a sustainable energy future. Nature 2012, 488, 294-303. [CrossRef] [PubMed]

2. Lee, S.; Kim, T.; Jack, H.; Wayne, W.; Jeffrey, A. Joining Technologies for Automotive Lithium-Ion Battery Manufacturing: A Review. ASME Conf. Proc. 2010, 1, 541-549. [CrossRef]

3. Das, A.; Li, D.; Williams, D.; Greenwood, D. Joining Technologies for Automotive Battery Systems Manufacturing. World Electr. Veh. J. 2018, 9, 22. [CrossRef]

4. Zhou, Y.; Gorman, P.; Tan, W.; Ely, K.J. Weldability of thin sheet metals during small-scale resistance spot welding using an alternating-current power supply. J. Electron. Mater. 2000, 29, 1090-1099. [CrossRef]

5. Lee, S.J.; Nakamura, H.; Kawahito, Y.; Katayama, S. Effect of welding speed on microstructural and mechanical properties of laser lap weld joints in dissimilar $\mathrm{Al}$ and $\mathrm{Cu}$ sheets. Sci. Technol. Weld. Join. 2013, 19, 111-118. [CrossRef]

6. Biro, E.; Weckman, D.C.; Zhou, Y. Pulsed Nd:YAG laser welding of copper using oxygenated assist gases. Met. Mater. Trans. A 2002, 33, 2019-2030. [CrossRef]

7. Das, A.; Li, D.; Williams, D.; Greenwood, D. Weldability and shear strength feasibility study for automotive electric vehicle battery tab interconnects. J. Braz. Soc. Mech. Sci. Eng. 2019, 41, 54. [CrossRef]

8. Kim, T.; Yum, J.; Hu, S.; Spicer, J.; Abell, J. Process robustness of single lap ultrasonic welding of thin, dissimilar materials. CIRP Ann. 2011, 60, 17-20. [CrossRef]

9. Zhang, W.; Ao, S.; Oliveira, J.; Li, C.; Zeng, Z.; Wang, A.; Luo, Z. On the metallurgical joining mechanism during ultrasonic spot welding of NiTi using a Cu interlayer. Scr. Mater. 2020, 178, 414-417. [CrossRef]

10. Zhang, W.; Ao, S.S.; Oliveira, J.P.; Zeng, Z.; Luo, Z.; Hao, Z.Z. Effect of ultrasonic spot welding on the mechanical behaviour of NiTi shape memory alloys. Smart Mater. Struct. 2018, 27, 085020. [CrossRef]

11. Ying, L.; Haseung, C.; Wayne, C.; Teresa, R.; Jack, H.; Elijah, K.; Abell, J. Joint Formation in Multilayered Ultrasonic Welding of Ni-Coated Cu and the Effect of Preheating. J. Manuf. Sci. Eng. 2018, 140, 111003. [CrossRef]

12. Elangovan, S.; Prakasan, K.; Jaiganesh, V. Optimization of ultrasonic welding parameters for copper to copper joints using design of experiments. Int. J. Adv. Manuf. Technol. 2010, 51, 163-171. [CrossRef]

13. Yang, J.; Cao, B.; Lu, Q. The Effect of Welding Energy on the Microstructural and Mechanical Properties of Ultrasonic-Welded Copper Joints. Materials 2017, 10, 193. [CrossRef] [PubMed]

14. Arimoto, K.; Sasaki, T.; Doi, Y.; Kim, T. Ultrasonic Bonding of Multi-Layered Foil Using a Cylindrical Surface Tool. Metals 2019, 9 , 505. [CrossRef] 
15. Zhanzhan, S.; Zhengqiang, Z.; Yifu, Z.; Hua, Z.; Qiankun, X. Recrystallization Behavior of a Pure Cu Connection Interface with Ultrasonic Welding. Metals 2021, 11, 61. [CrossRef]

16. Das, A.; Masters, I.; Williams, D. Process robustness and strength analysis of multi-layered dissimilar joints using ultrasonic metal welding. Int. J. Adv. Manuf. Technol. 2018, 101, 881-900. [CrossRef]

17. Das, A.; Barai, A.; Masters, I.; Williams, D. Comparison of Tab-To-Busbar Ultrasonic Joints for Electric Vehicle Li-Ion Battery Applications. World Electr. Veh. J. 2019, 10, 55. [CrossRef]

18. Das, A.; Ashwin, T.; Barai, A. Modelling and characterisation of ultrasonic joints for Li-ion batteries to evaluate the impact on electrical resistance and temperature raise. J. Energy Storage 2019, 22, 239-248. [CrossRef]

19. Lee, S.S.; Kim, T.H.; Hu, S.J.; Cai, W.W.; Abell, J.A. Joining technologies for automotive lithium-ion battery manufacturing: A review. In Proceedings of the International Manufacturing Science and Engineering Conference, Erie, PA, USA, 12-15 October 2010; pp. 541-549. 